\title{
PUBLIC POLICY AS AN EXCEPTION TO FREE MOVEMENT WITHIN THE INTERNAL MARKET AND THE EUROPEAN JUDICIAL AREA: A COMPARISON
}

\begin{abstract}
Tena Hoško*
Summary: This article compares the public policy exception to free movement of goods, services, persons and capital (the four freedoms) with the public policy exception to free movement of judgments (the fifth freedom). A comparison is made on the basis of the following elements: types of public policy (domestic, international, purely international; European; substantive and procedural), restrictiveness of interpretation, variability, content, nature and the addressees of protection. The conclusion is that there is only one concept of public policy that varies from time to time and from Member State to Member State, although there are some differences in the operation of the uses in the two areas of public policy.
\end{abstract}

\section{Introduction}

The European Union (hereinafter: EU) is based on the free movement of goods, services, persons, and capital, ${ }^{1}$ known as the four freedoms. In order to secure the impeccable functioning of the internal market, a 'fifth freedom"2 has emerged in the Brussels Convention ${ }^{3}$ and the following Brussels I Regulation ${ }^{4}$ - the free movement of judgments. ${ }^{5}$ Although all of these freedoms are of utmost importance for the EU, there are some restrictions to them. Restrictions are necessary since there are still specificities of each Member State's legal order that need to be safeguarded, notwithstanding the well-functioning internal market. ${ }^{6}$ One of these is

\footnotetext{
Faculty of Law, University of Zagreb. The author is grateful to Dr Justin Borg-Barthet for his comments on an earlier draft of the paper. All errors are the author's alone.

1 Treaty on the Functioning of the European Union (Lisbon Treaty), Titles II and IV.

2 This paper will be limited to the public policy exceptions to the five freedoms. For a comprehensive review of public policy in the EU, see Tim Corthaut, EU Ordre Public (Wolters Kluwer 2012).

3 Convention on jurisdiction and the enforcement of judgments in civil and commercial matters (Brussels Convention).

4 Council Regulation (EC) No 44/2001 of 22 December 2000 on jurisdiction and the recognition and enforcement of judgments in civil and commercial matters (Brussels I Regulation) [2001] OJ L12/1.

5 Brussels I Regulation (n 4), Recital 6 of the Preamble; Jerca Kramberger Škerl, 'European Public Policy (With an Emphasis on Exequatur Proceedings)' (2011) 7 JPIL 461, 480.

6 Corthaut (n 2) 79.
} 
the public policy of the Member State of destination, or the Member State of recognition and enforcement of the foreign judgment.

The modern private international law doctrine of public policy was developed in the $19^{\text {th }}$ century. Joseph Story argued that 'foreign laws which are repugnant to fundamental principles of the lex fori, or to religion or morality, cannot claim adoption under the general comity of nations'. ${ }^{7}$ Already then, it was held that the State should be allowed to protect its own fundamental principles when there was a dispute involving a foreign element. Such importance of public policy was perceived by the founding EU Member States who 'realised that member states may wish to enhance different values and differentiate in the way they deal with certain activities'. ${ }^{8}$ The public policy exception to the four freedoms was thus introduced from the start in the Treaty of Rome of $1957 .{ }^{9}$ Although the European Communities, now the European Union, had the convergence of laws and economic policy as their goal from the very beginning, ${ }^{10}$ it was reasonable to include such an exception and not to expect complete equality between the Member States.

The public policy of a state is not easy to define due to its variability in space and time. ${ }^{11}$ However, the Court of Justice of the EU (hereinafter: CJEU, the Court) has developed some standards for its application both in the context of public policy as a justification for the restriction of the four freedoms (Article 36 of the Treaty on the Functioning of the European Union (hereinafter: TFEU) for goods, Article 45 TFEU for workers, Article 52 TFEU for establishment, Article 65 TFEU for capital and payments (hereinafter: the four freedoms public policy)) ${ }^{12}$ and public policy as a justification for the restriction of the fifth freedom (Article 34(1) Brussels I (hereinafter: the judgments public policy)). ${ }^{13}$ It is thus to be established whether a parallel can be drawn between the two. Rushed conclusions are unwelcome because there are both similarities and differences between the two. ${ }^{14}$ The CJEU, willingly or not, is interpreting

\footnotetext{
7 Joseph Story, Commentaries on the Conflict of Laws: Foreign and Domestic, in Regard to Contracts, Rights, and Remedies, and Especially in Regard to Marriages, Divorces, Wills, Successions, and Judgments (2nd edn, Edmund Hatch Bennett 1872) para 373ff.

8 Catherine Kessedjian, 'Public Order in European Law' (2007) 1 Erasmus LR, 25, 28.

9 Treaty establishing the European Economic Community of 25 March 1957, art 36 for goods, art 48 for workers and art 56 for establishment. Art $73 \mathrm{~d}$ for capital and payments was added by the Maastricht Treaty on Establishing European Community of 7 February 1992.

10 ibid, Preamble and art 2.

11 Stéphanie Francq, 'Article 34' in Ulrich Magnus and Peter Mankowski (eds), Brussels I Regulation (1st edn, Sellier 2007) para 15.

12 Lisbon Treaty (n 1),

13 The paper will focus on the Brussels I Regulation since there is no CJEU case law regarding the other legislation on recognition and enforcement of judgments.

14 Examination of all the linguistic versions, except Gaelic which is inaccessible for Brus-
} 
the usages of public policy in both areas in a similar fashion, but their addressees, content, nature and operation are sometimes different. Still, it is submitted that the difference in usage is not of such a nature as to amount to the creation of two different notions, or to the splitting of the one into two separate notions.

This paper will firstly present public policy as used within the restriction of the four freedoms and then in EU private international law. One early CJEU decision for each area will be elaborated - Van Duyn $v$ Home Office ${ }^{15}$ and Krombach $v$ Bamberski. ${ }^{16}$ They were mostly followed in the later CJEU jurisprudence and they depict the basic features of the operation and content of public policy. Other relevant case law will be used throughout the paper. After that, several types of public policy will be discussed - domestic, international and purely international; European; substantive and procedural public policy - in order to see how they act in the context of the five freedoms. The paper will then discuss the similarities and differences between the usages of public policy in the two areas in the EU. The similarities are found in its strict interpretation, the variability of the notion, and the violation of a fundamental value needed to establish contrariety of public policy. The differences are based on the discriminatory nature of the four freedoms public policy, on the protection of different addressees' human rights and on the protection of an economic interest. Lastly, the paper will assess the comparison of the 'two public policies' in order to determine whether there is only one notion of public policy within the EU.

\section{Public policy in the EU internal market law}

\subsection{General observations}

It is a mission of the EU to ensure free circulation of four factors of production - goods, services, persons, and capital - since this is the only way to create an economically connected community (an internal market), which is the primary goal of the EU. The mutual recognition of the four freedoms between Member States does not produce absolute rights. Restrictions are allowed, but are to be applied restrictively. As a restric-

sels I, of the relevant legislation shows that there is no difference in naming the two exceptions in most languages. However, differences occur in Bulgarian ('публичната политика' and 'обществен ред'), Danish ('grundlæggende retsprincipper' and 'offentlige orden'), Finnish ('oikeusjärjestyksen perusteita' and 'yleisen järjestyksen'), Hungarian ('Közrendjével' and 'közrend'), Maltese ('l-istrategijia pubblika' and 'ordni pubbliku') and Swedish ('rättsordningen' and 'allmän ordning'). Without going into linguistic nuances, the private international law notion is named 'public policy' and the Treaty notion could be best translated as 'public order' or 'law and order'. For more, see Kessedjian (n 8) 25-26.

15 Case 41-74 Yvonne van Duyn v Home Office [1974] ECR 01337.

16 Case C-7/98 Dieter Krombach v André Bamberski [2000] ECR I-01935. 
tion to the four freedoms, public policy stands side by side with public security and even public morality, the protection of the health and life of humans, animals or plants, the protection of national treasures possessing artistic, historic or archaeological value, and the protection of industrial and commercial property in the case of the free movement of goods (Article 36 TFEU). Therefore, public policy does not include the other enumerated exceptions. In the case of judgments public policy, there are no similar exceptions to the ones for the four freedoms. However, the Brussels I Regulation adds several more reasons for refusing recognition and enforcement of a foreign judgment: breach of the defendant's right to be heard due to lack of adequate service, an irreconcilable domestic judgment, and an irreconcilable foreign judgment that is susceptible to recognition and enforcement in the state of recognition and enforcement. ${ }^{17}$

Although the public policy exception exists for all four freedoms and is most often interpreted in an analogous fashion, ${ }^{18}$ there are some differences in the application of the exception. By way of example, public policy is often considered together with public security in the case of free movement of persons. ${ }^{19}$ When deciding on a person's right to enter and reside in a foreign Member State, his or her personal conduct is relevant and an analysis of both restrictions at the same time provides for a complete review. ${ }^{20}$ Still, the nuances in approach to the four freedoms public policy are not so major as to impede a comparison of the four freedoms and the free movement of judgments.

\subsection{Van Duyn $v$ Home Office - how the exception operates}

In one of the most important judgments dealing with the direct applicability of EU law and exceptions to the free movement of workers, Van Duyn $v$ Home Office, the dispute arose before the English court. The case involved a Dutch citizen, Mrs Van Duyn, who was denied leave to enter the United Kingdom since she was to be employed by the Church of Scientology whose activity was disapproved by the British Government.

17 Brussels I Regulation (n 4) art 34/2-4. These other reasons prevail in application over the public policy exception (see Aurelio Lopez-Tarruella, The Public Policy Clause in the System of Recognition and Enforcement of the Brussels Convention' (2000-2001) ELF 122, 126-127.

18 Alan Dashwood and Derrick Wyatt, Wyatt and Dashwood's European Union Law (6th edn, Hart 2011) 571.

19 See eg Case 30-77 Régina v Pierre Bouchereau [1977] ECR 1977 01999; Joined cases 115 and 116/81 Rezguia Adoui v Belgian State and City of Liège; Dominique Cornuaille $v$ Belgian State [1982] ECR 01665; Catherine Barnard, The Substantive Law of the EU: The Four Freedoms (3rd edn, OUP 2010) 481.

20 Barnard (n 19) 482-485. 
In the preliminary ruling procedure, the national court firstly asked whether the provisions on free movement of workers and on justifications to their restrictions stemming from the Treaty and Directive No 64/221 of 25 February 1964 on the co-ordination of special measures concerning the movement and residence of foreign nationals were directly applicable. The CJEU held that those provisions 'confer on individuals rights which are enforceable by them in the courts of a member state and which the national courts must protect ${ }^{21}$ and are to be applied directly by the national courts.

The second question answered by the CJEU dealt with the restriction to free movement of workers based on public policy. The activities of the Church of Scientology were not unlawful in the United Kingdom. However, the State considered them to be socially harmful and employed administrative measures to counteract them. The CJEU held that the lack of illegality of a certain conduct does not lead to the impossibility to invoke the violation of public policy and concluded that the particular circumstances justifying recourse to the concept of public policy may vary from one country to another and from one period to another'. ${ }^{22}$ It was emphasised that although the United Kingdom does not impose similar measures on its own nationals in similar circumstances, it is not prohibited under the principle of non-discrimination to prevent foreign nationals to enter its territory. As the CJEU said, this is a consequence of the international law principle that a state cannot prohibit its own nationals from entering its territory. ${ }^{23}$

The CJEU also tackled the question of the scope of applicability of the restriction to the free movement of workers based on public policy by stating that 'the concept of public policy in the context of the Community and where, in particular, it is used as a justification for derogating from the fundamental principle of freedom of movement for workers, must be interpreted strictly'. ${ }^{24}$ The framework for this strict interpretation was set in subsequent case law where the CJEU concluded that only 'a genuine and sufficiently serious threat to the requirements of public policy affecting one of the fundamental interests of society ${ }^{25}$ could amount to a violation of public policy. The main lessons to be learned from the Court's interpretation of the public policy exception are best reiterated in a recent case:

The Court has always emphasised that while Member States essentially retain the freedom to determine the requirements of

${ }^{21}$ Van Duyn (n 15) para 15.

22 ibid, para 18.

23 ibid, para 22.

24 ibid, para 18.

25 Bouchereau (n 19) para 35. 
public policy and public security in accordance with their national needs, which can vary from one Member State to another and from one era to another, the fact still remains that, in the European Union context and particularly as justification for a derogation from the fundamental principle of free movement of persons, those requirements must be interpreted strictly, so that their scope cannot be determined unilaterally by each Member State without any control by the institutions of the European Union. ${ }^{26}$

\section{Public policy in the EU private international law}

\subsection{General observations}

The secondary legislation regulating the ever more important fifth freedom in the EU, namely Articles 34 and 57 of the Brussels I Regulation, ${ }^{27}$ Articles 22 and 13 of Brussels II bis, ${ }^{28}$ Articles 24 and 34 of the Maintenance Regulation, ${ }^{29}$ and Article 40 of the Succession Regulation ${ }^{30}$ allow for non-recognition or non-enforcement of judgments on the basis of the public policy of the state of recognition. Besides, violation of the public policy of the forum might be an excuse for the non-application of foreign law under Article 21 of the Rome I, ${ }^{31}$ Article 26 of the Rome II, ${ }^{32}$ and Article 12 of the Rome III $^{33}$ regulations and Article 25 of the Succession Regula-

\footnotetext{
${ }_{26}$ Case C-434/10 Petar Aladzhov $v$ Zamestnik director na Stolichna direktsia na vatreshnite raboti kam Ministerstvo na vatreshnite raboti [2011] ECR I-11659, para 34.

27 Brussels I Regulation (n 4).

28 Council Regulation (EC) No 2201/2003 of 27 November 2003 concerning jurisdiction and the recognition and enforcement of judgments in matrimonial matters and the matters of parental responsibility, repealing Regulation (EC) No 1347/2000 OJ L338/1.

${ }_{29}$ Council Regulation (EC) No 4/2009 of 18 December 2008 on jurisdiction, applicable law, recognition and enforcement of decisions and cooperation in matters relating to maintenance obligations $O J L 7 / 1$. It has to be mentioned that due to two different recognition and enforcement systems in the Maintenance Regulation, the public policy exception only applies to maintenance decisions coming from states not bound by the Hague Protocol of 23 November 2007 on the Law Applicable to Maintenance Obligations, namely Denmark and the United Kingdom.

30 Regulation (EU) No 650/2012 of the European Parliament and of the Council of 4 July 2012 on jurisdiction, applicable law, recognition and enforcement of decisions and acceptance and enforcement of authentic instruments in matters of succession and on the creation of a European Certificate of Succession OJ L201/107.

31 Regulation (EC) No 593/2008 of the European Parliament and of the Council of 17 June 2008 on the law applicable to contractual obligations (Rome I) OJ L177/6.

${ }^{32}$ Regulation (EC) No 864/2007 of the European Parliament and of the Council of 11 July 2007 on the law applicable to non-contractual obligations (Rome II) OJ L199/40.

${ }^{33}$ Council Regulation (EU) No 1259/2010 of 20 December 2010 implementing enhanced cooperation in the area of the law applicable to divorce and legal separation (Rome III) OJ 2010 L343/10.
} 
tion. ${ }^{34}$ The public policy exception as used in EU private international law was already part of the national laws in Europe E $^{35}$ and today it continues to form a valuable device for the protection of the domestic legal order.

Notwithstanding the fact that the EU strives to create an 'ever closer Union', ${ }^{66}$ the EU Member States have not yet reached such a similarity in basic principles, fundamental values and protection of human rights to completely abandon the public policy exception. ${ }^{37}$ Indeed, this exception to recognition and enforcement of foreign judgments has been kept in the Recast of the Brussels I Regulation that will come into force in January 2015. ${ }^{38}$ This basically means that in the case of a dispute with a foreign element, Member States may avail themselves of the negative function ${ }^{39}$ of the public policy to prevent the unwanted effects ${ }^{40}$ of foreign law or of a foreign judgment by avoiding its application or recognition and enforcement.

\subsection{The Krombach $v$ Bamberski judgment - how the doctrine operates}

In order to show the operation of the concept, the landmark Krombach $v$ Bamberskit judgment dealing with the public policy exception to the recognition and enforcement of foreign judgments in the Brussels I Regulation will be presented. Mr Krombach was under preliminary investigation in Germany due to alleged liability for negligence in relation to the death of Mr Bamberski's daughter. The investigation was discontinued, but on Mr Bamberski's initiative the proceedings were started in France where jurisdiction was based on the victim's French nationality. In the proceedings, Mr Krombach did not appear in person and was subject to contempt proceedings in which his counsel was not allowed to appear. Mr Krombach was found guilty of involuntary manslaughter and $\mathrm{Mr}$ Bamberski was given monetary compensation. The case only deals with

\footnotetext{
34 Succession Regulation (n 30).

35 P Jenard, 'Report on the Convention on jurisdiction and the enforcement of judgments in civil and commercial matters (signed at Brussels, 27 September 1968)' (Jenard Report) OJ C59/1, 3-6.

36 Lisbon Treaty (n 1), Recital 13 of the Preamble.

37 Paul Beaumont and Emma Johnston, 'Can Exequatur Be Abolished In Brussels Whilst Retaining a Public Policy Defence?' (2010) 6 JPIL 247, 277-278. According to Lopez-Tarruella ( $\mathrm{n} 17$ ) 127, if the law regulated by the Brussels I Regulation becomes harmonised, no public policy exception will be necessary.

38 Regulation (EU) No 1215/2012 of the European Parliament and of the Council of 12 December 2012 on jurisdiction and the recognition and enforcement of judgments in civil and commercial matters (recast) OJ L351/1, arts 45 and 46.

39 Jan Kropholler, Internationales Privatrecht (6th edn, Mohr Siebeck 2006) para 36 I.

40 Only the effect of recognition and enforcement of the foreign judgment can violate the public policy, not the foreign judgment itself. Jenard Report (n 35) 44.

${ }^{41}$ Krombach (n 16).
} 
the civil implications of the criminal judgment, ie the monetary compensation given to $\mathrm{Mr}$ Bamberski for the loss of his daughter, since criminal proceedings fall out of the scope of the application of the Brussels I Regulation. When the recognition and enforcement of the judgment was sought in Germany, the appeal came to the Bundesgerichtshof (German Supreme Court) due to the violation of the right to a fair trial since $\mathrm{Mr}$ Krombach was not heard during the proceedings.

The German court stayed the proceedings and referred three questions to the CJEU. The national court wanted to know whether the public policy exception under the then applicable Brussels Convention ${ }^{42}$ may be interpreted to encompass firstly the fact that the foreign jurisdiction was based on exorbitant rules and secondly the violation of the right to a fair trial. Regarding the first question, the CJEU decided that Member States are not allowed to review a foreign court's jurisdiction as the Convention itself says in Article 28, even if the jurisdiction is wrongly based solely on the victim's nationality. ${ }^{43}$ With regard to the second part, the CJEU decided that Member States may interpret the notion in accordance with their own conceptions, but the limits are to be determined by the CJEU itself, so public policy is 'no longer a purely domestic matter'. ${ }^{44}$ It was stated that domestic public policy is endangered when the recognition and enforcement of a judgment 'would be at variance to an unacceptable degree with the legal order of the State in which enforcement is sought inasmuch as it infringes a fundamental principle'. ${ }^{45}$ Since the 'right to a fair trial occupies a prominent position in the organisation and conduct of a fair trial and is one of the fundamental rights deriving from the constitutional traditions common to the Member States', ${ }^{46}$ the CJEU allowed the refusal of recognition and enforcement of a judgment issued in violation of this right. The third question was a combination of the first two questions and was not answered since the second one had been answered positively.

Although the case was decided under the Brussels Convention, there should be continuity of case law between the Convention and the Regulation. As stated in Falco Privatstiftung, ${ }^{47}$ the two instruments follow the same structure and principles. Looking at the public policy exception specifically, the provision retains the same structural position within the

\footnotetext{
42 Brussels Convention (n 3) art 27(1).

43 Krombach (n 16) para 33.

44 Manuel Rui Moura Ramos, 'Public Policy in the Framework of the Brussels Convention: Remarks on Two Recent Decisions by the European Court of Justice' [2000] YPIL 25, 28.

45 Krombach (n 16) para 37.

46 Krombach (n 16) para 38.

47 In case C-533/07 Falco Privatstiftung and Thomas Rabitsch v Gisela Weller-Lindhors [2009] ECR I-03327, paras 48-51.
} 
Regulation as one of the few very limited grounds for refusal of recognition and enforcement of a foreign judgment. ${ }^{48}$ The wording has changed, since the Regulation added the word 'manifestly' to the expression 'contrary to public policy'. This change is irrelevant for the continuity of case law because public policy was used only in 'exceptional cases'49 even under the Brussels Convention and it is thought that a very restrictive interpretation existed even before the inclusion of that word. ${ }^{50}$ The inclusion only strengthens the point that this restriction of free movement of judgments should be invoked in exceptional circumstances. ${ }^{51}$

The Krombach judgment gives limited guidance to Member States on what constitutes infringement of public policy. In order for public policy to be justly invoked, three cumulative requirements have to be fulfilled: that there is a notable discrepancy between the rule applied in the state of origin and a rule of the state of recognition, that there is a violation of a fundamental principle in the state of recognition and enforcement due to that very discrepancy, and that this violation of a fundamental principle constitutes a 'manifest breach of a rule of law regarded as essential in the legal order of the State in which enforcement is sought'. ${ }^{52}$ The Court put forward the limits of the notion, leaving Member States to decide what is essential for their legal order. ${ }^{53}$ This essentiality criterion is the main tool of discretion given to Member States, which will enable them to create their own public policy depending on different features of their legal order. Still, the Member States cannot use the discretion too freely seeing that the Court has given a strict interpretation of public policy.

Now the question arises whether one could claim that this public policy exception is equal or applied in an equal fashion to the judgments public policy. Prima facie estimation could lead to the conclusion that since the purpose is similar, that is, restricting freedom of movement on the basis of a violation of fundamental principles or the 'public good', ${ }^{4}$ as stated in Van Duyn, the usage in both areas should be the same. However, it will be shown that although similar, the uses of public policy in

\footnotetext{
48 Compare art 27 of the Brussels Convention (n 3) and art 34 of the Brussels I Regulation (n 4).

49 Krombach (n 16) para 44; Ruprecht-Karls-Universität Heidelberg, 'Report on the Application of Regulation Brussels I in the Member States (Heidelberg Report)' Study JLS/ C4/2005/03 Final Version September 2007, para 543 <http://ec.europa.eu/civiljustice/ news/docs/study_application_brussels_1_en.pdf> accessed 5 June 2014.

50 Haris P Meidanis, 'Public Policy and Ordre Public in the Private International Law of the EU: Traditional Positions and Modern Trends' (2005) 30 ELR 95, 101.

51 Christopher M V Clarkson and Jonathan Hill, The Conflict of Laws (4th edn, OUP 2011) 51.

52 Krombach (n 16) para 37.

53 Meidanis (n 50) 101-102.

54 Van Duyn (n 15) para 18.
} 
the two areas are not identical. But first, several types of public policy will be demonstrated and their use in the four freedoms and in the judgments public policy will be evaluated.

\section{Which public policy?}

\subsection{Domestic, international and purely international public policy}

Public policy is always national and protects domestic interests. ${ }^{55}$ However, there are several types or levels of public policy occurring in each State. In private international law, there is a distinction between so-called 'international' and 'domestic' public policy which comes down to the level of protection of the endangered interest. ${ }^{56}$ In cases with a foreign element, only the violation of the international level of national public policy may be invoked since it aims to protect the very essential values that should not be neglected even in internationalised disputes. ${ }^{57}$ This is analogous to the requirement of restrictive interpretation; only the very basic values deserve protection when restrictions within the EU are considered. Therefore, in both areas of usage of public policy, only the international one is to be protected. ${ }^{58}$

There is, however, another type of public policy - 'purely international' - which is at stake when an international law obligation or a rule would be infringed if the judgment was enforced or if the four freedoms were allowed free circulation. This is also part of the national public policy, but there is a specific source of obligation behind the domestic interest, ie an international law obligation that needs to be respected by the state concerned. ${ }^{59}$ It was submitted that this type of public policy could also be protected in the case of recognition and enforcement of foreign judgments. ${ }^{60}$ Beaumont and Johnston give an example of a mistaken breach of a UN sanction in the Member State of origin which could lead to enforcement in another Member State if purely international public policy is not invoked. ${ }^{61}$ There is no reason why violation of such a public policy could not lead to restrictions to the four freedoms. An example

\footnotetext{
55 Van Duyn (n 15) para 4 for the four freedoms, and art 34/1 of the Brussels I Regulation (n 4) for the fifth freedom.

56 It was firstly developed in France as a distinction between 'ordre public interne' and 'ordre public externe'. Kent Murphy, 'The Traditional View of Public Policy and Ordre Public in Private International Law' (1981) 11 GaJICL 591, 596.

57 Francq (n 11) paras 16-17.

58 Christoph Liebscher, 'European Public Policy: A Black Box?' (2000) 17 J Intl Arb 73, 74.

59 Cf Luigi Fumagalli, 'EC Private International Law and the Public Policy Exception: Modern Features of a Traditional Concept' (2004) 6 YPIL 171, 179.

60 Alex Mills, 'The Dimensions of Public Policy in Private International Law' (2008) 4 JPIL 201, 215; Beaumont and Johnston (n 37) 258-259.

61 Beaumont and Johnston (n 37) 259.
} 
could also be a UN sanction directed against a Member State national whose free movement could be restricted on that basis or whose assets were frozen so the free movement of capital would be restricted. Still, the national court would have to conduct the test given in the CJEU's case law in order to establish whether the public policy exception could be used. Already in Kadi, the CJEU made it clear that it has competence to review compliance of EU law that transposes international law with some other piece of EU legislation, ${ }^{62}$ and has thus accepted a 'sharply dualist tone in its approach to the international legal order'. ${ }^{63}$ This means that international law norms will 'gain validity in EU law only if they comply with EU constitutional primary law and in particular with EU fundamental rights'. ${ }^{64}$ Although Kadi does not effectively solve the question of the hierarchy of norms, ${ }^{65}$ national courts surely need to observe the standard set in the relevant CJEU case law regarding public policy when it comes to questions of primary EU law (the four freedoms) and fundamental rights (all the five freedoms).

\subsection{European public policy}

In Eco Swiss $v$ Benetton, ${ }^{66}$ the CJEU stated that Article 101 (ex Article 81 ) of the Lisbon Treaty is to be considered a part of the Member States' public policy. ${ }^{67}$ The question arose before the Dutch Supreme Court, Hoge Raad, whether an arbitral award enforcing a licence agreement should be annulled based on public policy due to a lack of requirements under Article 101 of the Treaty (ie notification to the Commission) which renders the agreement invalid. Under Dutch law, violation of competition law was not considered to be a violation of national public policy. Even more, the sought annulment was time barred according to Dutch law since the parties should have started annulment proceedings based on the interim award dealing with the same question. The CJEU stated that although the national court must consider the application of the mentioned provision as part of its national public policy, it is not required to review the award if national procedural rules restrain it from doing

\footnotetext{
${ }^{62}$ Joined cases C-402 \& 415/05P Kadi \& Al Barakaat Int'l Found v Council \& Comm'n [2008] ECR I-6351, paras 287-290.

63 Graine de Burca, 'The European Court of Justice and the International Legal Order After Kadi' (2010) 51 Harv Intl LJ 1, 2.

64 Samantha Besson, 'European Legal Pluralism after Kadi’ (2009) 5 EuConst 5 237, 245.

65 ibid.

${ }^{66}$ Case C-126/97 Eco Swiss China Time Ltd v Benetton International NV ECR [1999] I 03055.

67 Confirmed in Joined cases C-295/04 to C-298/04 Vincenzo Manfredi v Lloyd Adriatico Assicurazioni SpA (C-295/04), Antonio Cannito v Fondiaria Sai SpA (C-296/04) and Nicolò Tricarico (C-297/04) and Pasqualina Murgolo (C-298/04) v Assitalia SpA ECR [2006] I-06619.
} 
so. The Court has thus introduced a notion of EU public policy that was confirmed in subsequent case law. ${ }^{68}$

The implications of this decision could be explained in three different ways. Firstly, it could be inferred that the CJEU has departed from Krombach and has imposed on national courts the content of public policy creating a European or EU public policy. ${ }^{69}$ The other view is that the CJEU only did its job in securing the correct interpretation and application of EU law by confirming that some EU provisions deserve to be considered part of national public policy, which only reiterates Krombach and the CJEU's role in setting limits to the notion. ${ }^{70}$ Thirdly, Haegen sees the Eco Swiss judgment as CJEU's manipulation of the public policy device since the arbitrators may never request a preliminary ruling from the CJEU and this was the way to ensure the compliance of arbitral proceedings with EU law. ${ }^{71}$ Perhaps the middle approach would be the best - EU law is part of national law, and since only the CJEU is to interpret EU law, it is to determine which of it is to be considered part of national public policy. ${ }^{72}$ This interpretation does not support the creation of a European public policy as opposed to a national one; it just acknowledges that there is an EU law level in national public policy. ${ }^{73}$ This is confirmed in the Giuliano and Lagarde Report on the Rome Convention. ${ }^{74}$ Looking at Eco Swiss together with Maxicar where the CJEU decided that the misapplication of the Treaty provisions does not always form a violation of national public policy, ${ }^{75}$ it is seen that not each and every norm coming from the EU, especially the Treaty, forms such a fundamental rule to place it within the notion of public policy. ${ }^{76}$ It is always to be kept in mind

\footnotetext{
68 Case C-168/05 Elisa Maria Mostaza Claro v Centro Móvil Milenium SL [2006] ECR I-10421; Case C-40/08 Asturcom Telecomunicaciones SL v Cristina Rodríguez Nogueira [2009] ECR I-9579.

69 See George A Bermann, 'Reconciling European Union Law Demands with the Demands of International Arbitration' (2011) 34 Fordham Intl LJ 1193, 1202; Olivier van der Haegen, 'European Public Policy in Commercial Arbitration: Bridge Over Troubled Water?' (2009) 16 MJ 449, 453 fn 14.

70 Meidanis (n 50) 105.

71 Haegen (n 69) 456.

72 Cf Fumagalli (n 59) 179-180.

73 Paolo Bertoli, 'European Integration and Private International Law' (2006) 8 YPIL 375, 409.

74 'It goes without saying that this expression [ordre public] includes Community public policy, which has become an integral part of the public policy ('ordre public) of the Member States of the European Community'. M Giuliano and P Lagarde, 'Report on the Convention on the Law Applicable to Contractual Obligations' (1980) OJ C282/1, 38.

75 Case C-38/98 Régie nationale des usines Renault SA v Maxicar SpA and Orazio Formento [2000] I-02973, paras 31-34.

76 George A Bermann, 'Navigating EU Law and the Law of International Arbitration' (2012) 28 Arb Intl 397, 418
} 
that the notion of public policy deserves a very narrow application. ${ }^{77}$ In any case, the concept of EU public policy protects the EU and its interests primarily, whereas 'classical' public policy protects national law and interests. $^{78}$

In view of the foregoing, the question is whether there could be an EU layer of the four freedoms public policy. ${ }^{79}$ It is plausible that the CJEU would accept the public policy exception, for example, to restrict the provision of services from a company that has unduly been given state aid. However, it is to be kept in mind that in any application of public policy its violation must be obvious and severe. In the given example, the national court surely would not be the one to investigate whether the conditions have been fulfilled. It could rely on public policy if a breach of the procedure has already been established or if the breach is manifest enough to allow reliance on the public policy exception.

\subsection{Substantive $v$ procedural public policy}

In private international law, there is a distinction between substantive and procedural public policy. The classification depends on whether the substantive law standards or procedural law standards are in question. In the operation of public policy as a restriction to the fifth freedom, it is more often the case that the procedural aspect is endangered. ${ }^{80}$ The reason for this could firstly be found in the similarity of civil and commercial law and principles of Member States. Secondly, the prohibition of the review of merits under Articles 35 and 45/2 of the Brussels I Regulation leads to it being virtually impossible to claim violation of the substantive aspect of public policy. ${ }^{81}$ However, it is possible for substantive public policy to be at stake when, for example, the original judgment is obtained by fraud, and which is discovered only after the judgment has been issued. ${ }^{82}$ The most frequent consideration under procedural public policy is what is encompassed by the right to a fair trial expressed in Article 6 of the European Convention on Human Rights and Fundamental Freedoms. ${ }^{83}$ It was also confirmed by the CJEU that the Convention and the

\footnotetext{
77 According to Bermann (n 76) 419-120, EU public policy is interpreted more widely than private international law policy should be.

78 For some authors it is questionable whether anything is left for the Member States to protect at all. See eg Kassedijan (n 8).

79 For a general plea for an EU public policy, see Corthaut (n 2).

80 Burkhard Hess and Thomas Pfeiffer, 'Interpretation of the Public Policy Exception as referred to in EU Instruments of Private International and Procedural Law' (European Parliament 2011) <www.europarl.europa.eu/studies> accessed 5 June 2014, ch 4.1.1.

81 Francq (n 11) para 20.

82 Jan-Jaap Kuipers, 'The Right to a Fair Trial and the Free Movement of Civil Judgments' (2010) 6 Croatian Yearbook of European Law and Policy 41-42.

83 Hess and Pfeiffer (n 80) ch 4.1.2.
} 
case law interpreting it are of high importance when violations of human rights in respect of public policy restriction are questioned. ${ }^{84}$

On the other hand, if the distinction is transposed to the four freedoms public policy, substantive public policy will most probably more often be at stake. ${ }^{85}$ When applying the four freedoms public policy, there is no process relevant to free movement and that is why procedural standards will have lesser importance. This difference is based on the nature of what should circulate freely. In the case of judgments, there is always a procedural aspect preceding the judgments themselves. This is not the case with goods, services, workers and capital. However, it is possible for some procedural standards to be infringed, for example in the process of the formation of a company which would make another Member State prohibit the free movement of services provided by that company. It is unlikely that violations of such standards would be so grave as to violate public policy, especially its procedural character. Even more, even if the procedural rules are breached, the result is a favourable one since the person is allowed to exercise the right of establishment, and depriving the services of free movement would only increase the injustice and contravene the EU's aims.

In its Van der Weerd ${ }^{86}$ judgment, the CJEU gave an interpretation which could in part explain how the four freedoms procedural public policy should function. The dispute arose in the Netherlands between cattle breeders and the Minister for Agriculture, Nature and Food Quality in the application of measures dealing with the slaughter of cattle due to alleged disease. Although only one Member State was involved and the dispute deals with the relation of public policy and EU law, it might give some answers. The main question is whether the national court can invoke EU law ex officio in order to review the national administrative procedure. The CJEU stated that the national court has an obligation to review the relevant procedure only if the contrary would violate its public policy. However, if the national concept of public policy does not compel it to do so ex officio, neither does the principle of equivalence. ${ }^{87}$ According to

\footnotetext{
${ }_{84}$ Krombach (n 15) paras 25-27.

85 The classic examples deal with protection of fundamental freedoms such as dignity (Case C-36/02 Omega Spielhallen- und Automatenaufstellungs-GmbH v Oberbürgermeisterin der Bundesstadt Bonn [2004] ECR I-09609), public order and protection from crime (Case C-137/09 Marc Michel Josemans $v$ Burgemeester van Maastricht [2010] ECR I-13019), monetary policy (Case 7/78 Regina $v$ Thompson, Johnson and Woodiwiss [1978] ECR 2247) etc.

86 Joined cases C-222/05 to C-225/05 J van der Weerd and Others, H de Rooy sr and H de Rooy jr, Maatschap $H$ en $J$ van 't Oever and Others and BJ van Middendorp v Minister van Landbouw, Natuur en Voedselkwaliteit [2007] ECR I-04233.

$87 \mathrm{ibid}$, para 31 . The principle of equivalence means that it is for the domestic legal system of each Member State to designate the courts and tribunals having jurisdiction and to lay down the detailed procedural rules governing actions for safeguarding rights which individuals derive from Community law, provided, first, that such rules are not less favourable than those governing similar domestic actions (...).'. ibid, para 28.
} 
AG Maduro, the national court has to determine whether the relevant EU rules are protecting the same interest as the national public policy, which was not the case in Van der Weerd. ${ }^{88}$ Transposed to the domain dealt with in this contribution, this means that the national court should decide under its national concept of public policy whether the foreign procedure is to be reviewed and whether the violation is such as to create a breach of public policy by looking at the interest that the national public policy safeguards and the interest that the foreign procedure violated. Only if the two interests are concurrent and only if the violation is manifest is there a violation of the national procedural public policy.

The difference of uses of public policy in the two areas with respect to the two elaborated aspects (substantive and procedural) of public policy lies only in the frequency of the occurrence of one or the other and this is consequential to the nature of the judicial process which results in a judgment on the one side, and the four basic freedoms on the other side, and does not amount to a difference in the operation of the exception.

\section{Similarities between the usages of public policy in the two areas}

\subsection{Restrictive interpretation}

The CJEU has decided that restrictions based on both uses of public policy should be interpreted restrictively. ${ }^{89}$ The wording of the Brussels I Regulation states that the recognition and enforcement of a foreign judgment must be 'manifestly' contrary to public policy of the forum to be refused, whereas the word 'manifestly' is lacking from the provisions dealing with justifications of restriction of the four freedoms. This might suggest that refusal of recognition and enforcement of judgments should be interpreted even more restrictively. However, the requirement of manifest breach of the judgments public policy actually stems from the Krombach judgment that was codified in the Brussels I Regulation..$^{90}$ On the other side, strict interpretation of the four freedoms public policy stems from the CJEU's case law which was never codified, but that does not make it any less binding.

Strict interpretation means that the violation in both cases must be both obvious or manifest and serious; it has to violate a fundamental value or principle. This twofold restriction in reality produces the effect that the public policy restriction is only applied in a very limited number

\footnotetext{
88 J van der Weerd and Others (n 86), Opinion of AG Poiares Maduro, paras 36-39.

89 Four freedoms: Omega (n 85) para 30; Case C-319/06 Commission of the European Communities $v$ Grand Duchy of Luxemburg [2008] ECR I-04323, para 30. Free movement of judgments: Case C-414/92 Solo Kleinmotoren GmbH v Emilio Boch [1994] ECR I-2237, para 20; Krombach (n 15) para 44; Renault v Maxicar (n 74) para 26.

90 See (n 49-51) and the accompanying text.
} 
of cases. This is in accordance with the basic aim that the EU pursues, namely the creation of an internal market through free circulation of the four (five) basic freedoms. Since invoking public policy might lead to a restriction of the basic freedoms and thereby endanger the EU's goal of eliminating the barriers which divide Europe, ${ }^{91}$ it is reasonable that a restrictive interpretation was employed since, as always, exceptiones sunt strictissimae interpretationis. The narrowness of application is mirrored in a small number of judgments actually allowing for restrictions based on public policy, both regarding the four freedoms and the recognition and enforcement of judgments. ${ }^{92}$ This shows that strict interpretation is a valuable characteristic since otherwise the States, as well as the parties, might misuse the concept in order to evade their obligations. This could be detrimental to the uniform application of EU law, so the correct balance needs to be struck.

\subsection{Violation of a fundamental value}

When deciding on restrictions of free movement of capital in Scientology International, the CJEU observed, actually relying on Rutili ${ }^{93}$ on free movement of workers, that public policy may be 'relied on only if there is a genuine and sufficiently serious threat to a fundamental interest of society'. ${ }^{94}$ In Krombach, on the other hand, the CJEU held that recognition or enforcement of a foreign judgment may be refused if its effects would infringe a fundamental principle and 'the infringement would have to constitute a manifest breach of a rule of law regarded as essential in the legal order of the State in which enforcement is sought or of a right recognised as being fundamental within that legal order. ${ }^{95}$ What should be emphasised at this point is that public policy may be invoked only if there is a violation of a fundamental value, and in both cases fundamentality should be recognised by the Member State. The recognition of such fundamentality will usually be indicated in the constitutional order and legislation, as well as in the actions taken by the State leadership. ${ }^{96}$

\footnotetext{
91 Lisbon Treaty (n 1), Recital 3 of the Preamble.

92 For the four freedoms, especially free movement of workers, see Dashwood and Wyatt (n 18) 483 and for the fifth freedom see Hess and Pfeiffer (n 80) ch 3.2.1. Also, national case law published on Unalex (available at <http://www.unalex.eu/Judgment/JudgmentSearch.aspx> accessed on 24 August 2014) shows that there have been 48 published decisions involving the public policy exception from 2008 to 2013. Only in 7 decisions were recognition and enforcement refused based on that exception.

93 Case 36-75 Roland Rutili v Ministre de l'intérieur [1975] ECR 01219, para 28.

94 Case C-54/99 Association Eglise de scientologie de Paris and Scientology International Reserves Trust $v$ The Prime Minister [2000] ECR I-01335, para 17.

95 Krombach (n 16) para 37.

96 It has to be noted that the mere fact that certain conduct is penalised in the relevant Member State does not make such conduct contrary to public policy. Case 16/83 Criminal Proceedings against Karl Prantl [1984] ECR 1299, para 33.
} 
The CJEU has already confirmed that human rights do present such fundamental values and has allowed restriction on free movement of services and goods in Omega ${ }^{97}$ based on violation of human dignity, and violation of the right to a fair trial led to non-recognition of a foreign judgment in Krombach. The judgments differ from each other since in Omega the public policy violation was strictly based on the German view of human rights, ${ }^{98}$ whereas in Krombach the recognition was refused based not only on the German but also on the European concept of the right to a fair trial. ${ }^{99}$ Still, in both cases there was a belief that the right in question forms a fundamental value, but that might not be the case for all the fundamental rights. Although all the Member States are also signatories to the European Convention on Human Rights and Fundamental Freedoms (hereinafter: ECHR), the level of protection of human rights varies, as seen especially in the French and German example in Krombach. Even if the state does not find the right to be so fundamental as to include it in its domestic public policy, it cannot avoid encompassing the level of protection imposed by the ECHR since it forms a minimum of protection of human rights in the Member States, ${ }^{100}$ and consequently in the EU legal order. ${ }^{101}$ This does not mean that the protection of the rights arising from that instrument has to be absolute, but derogations must be in accordance with the conditions set in it. Only then will circumvention of the expected protection of human rights not violate the State's public policy. The same can be said for the Charter on Fundamental Rights. ${ }^{102}$

In any case, although a fundamental value has been violated, the principle of proportionality has to be observed. ${ }^{103}$ When deciding on a restriction to the four freedoms, national courts must assess whether there is a less restrictive measure that would attain the same aim and preserve

\footnotetext{
97 Omega (n 85). For a commentary of other cases involving a clash of fundamental rights and the four freedoms, see Sybe A de Vries, 'Balancing Fundamental Rights with Economic Freedoms According to the European Court of Justice' (2013) 9 Utrecht L Rev 169, 178-183.

98 Omega (n 85) paras 34-39.

99 Krombach (n 16) paras 38-40.

100 Stephen Hall, The European Convention on Human Rights and public policy exceptions to the free movement of workers under the EEC Treaty' (1991) 16 ELR 466, 474-475.

${ }^{101}$ Bosphorus Hava Yollari Turizm Ve Ticaret Anonim Sirketiv Ireland (2006) 42 EHRR 1, paras 160-165.

${ }^{102}$ Charter of Fundamental Rights of the European Union of 18 December 2000 OJ C364/01.

${ }^{103}$ Fumagalli (n 59) 178. De Vries (n 97) 188-191 holds that the proportionality test functions differently in different cases regarding balancing human rights and fundamental freedoms. These nuances, however, do not affect the comparison conducted in his paper.
} 
the endangered interest. ${ }^{104}$ AG Maduro explained in Leppik ${ }^{105}$ the proportionality test to which each restriction has to be subjected in detail. The test has four components - the already mentioned necessity component (the least restrictive measure), proportionality stricto sensu (the more important the interest, the greater restriction is allowed), suitability (the measure has to be suitable to achieve the desired aim) and there must be no arbitrary discrimination in any case.

A decision on recognition and enforcement of a judgment must also be scrutinised by raising the question of whether the restriction in the foreign state was proportionate to its goal in order to ascertain whether there was a violation of the forum public policy, ${ }^{106}$ although a detailed test for the judgments public policy has not been developed to the same extent as the one from Leppik. However, the Leppik conditions are implicitly contained in the public policy exception to the recognition and enforcement of judgments. Proportionality stricto sensu was confirmed in Gambazzi where the CJEU stated that the sanctions restricting the right to defence "may not, however, be manifestly disproportionate to the aim pursued'. ${ }^{107}$ The necessity test is contained in Article 48 of the Brussels I Regulation which allows for partial enforcement of the judgment whose recognition and enforcement is sought. ${ }^{108}$ Therefore, the Regulation itself promotes the application of the least restrictive measure. The suitability test is imminent to the refusal of recognition and enforcement of a foreign judgment since it reaches the desired goal. The judgment does not produce effect in the State of recognition and is thus unable to produce harmful effects. The prohibition of arbitrary discrimination relates to the whole body of EU law since it forms one of the general principles of EU law. ${ }^{109}$ Therefore, when applying the Brussels I Regulation, the Member

\footnotetext{
${ }_{104}$ Case C-55/94 Reinhard Gebhard $v$ Consiglio dell'Ordine degli Avvocati e Procuratori di Milano [1995] ECR I-4165, para 37; Case C-348/96 Criminal proceedings against Donatella Calfa [1999] ECR I-00011, paras 7, 9; Case C-100/01 Ministre de l'Intérieurv Aitor Oteiza Olazabal [2002] ECR I-10981, paras 43, 44; Joined cases C-482/01 and C-493/01 Georgios Orfanopoulos and Others and Raffaele Oliveri v Land Baden-Württemberg [2004] ECR I-05257, para 99; Omega (n 85) paras 36-38; Case C-434/10 Petar Aladzhov v Zamestnik director na Stolichna direktsia na vatreshnite raboti kam Ministerstvo na vatreshnite raboti [2011] ECR 00000, para 42.

105 Case C-434/04 Criminal proceedings against Jan-Erik Anders Ahokainen and Mati Leppik [2006] ECR I-09171, Opinion of AG Poiares Maduro.

106 Case C-394/07 Marco Gambazzi v Daimler Chrysler Canada Inc and CIBC Mellon Trust Company [2009] ECR I-02563, paras 32-33; Case C-619/10 Trade Agency Ltd v Seramico Investments Ltd [2012] ECR 00000, para 62.

107 Gambazzi (n 106) para 32.

108 ' 1 . Where a foreign judgment has been given in respect of several matters and the declaration of enforceability cannot be given for all of them, the court or competent authority shall give it for one or more of them. 2. An applicant may request a declaration of enforceability limited to parts of a judgment.'

${ }^{109}$ See eg Joined cases 117-76 and 16-77 Albert Ruckdeschel \& Co and Hansa-Lagerhaus Ströh \& Co $v$ Hauptzollamt Hamburg-St Annen; Diamalt AG v Hauptzollamt Itzehoe ECR
} 
States have to obey the general prohibition of discrimination envisaged in the Lisbon Treaty. ${ }^{110}$

Proportionality in the context of the four freedoms public policy operates once the need for restriction has been spotted. Only if the restriction is proportionate can it be used. On the other hand, in the judgments public policy, the proportionality test forms part both of the establishment of the public policy violation (proportionality strict sensu) and of the estimation of the actions to be taken after the violation has been established (the necessity test to decide upon partial recognition $\mathrm{v}$ nonrecognition). Although proportionality takes place in a different context and stage of the cognitive decision-making process in the use of public policy in the two areas, it serves the same aim - to balance the restriction of the five freedoms and the alleged public policy violation.

\subsection{Time and space variability of the notion and the CJEU's review of limits}

The previous sections infer that there is an autonomous framework of public policy at the EU level. The CJEU has given some basic guidelines as to the conditions which have to be fulfilled to constitute a public policy violation. However, the content of that framework has to be determined based on the specificities of the Member States and their basic values in the relevant period, as was decided for both the four freedoms and the judgments public policy. ${ }^{111}$ Meidanis was right to conclude that public policy 'has a chameleon ability to change from country to country in terms of method of intervention, terminology, structure, method of creation and - needless to say - content'. ${ }^{112}$ The nationality of public policy is preserved because, without it, the exception based on public policy would in large part become futile. If there was only one public policy concept shared by all the Member States, they would not have an opportunity to form restrictions based on their particular national values. ${ }^{113}$ The limits of the notion, however, are still set in the EU law and assessed by the $\mathrm{CJEU}^{114}$ since it is only its duty to interpret the EU law which aspires to create a functional internal market with the four (five) basic freedoms operating well.

[1977] 01753, para 7; Case C-442/00 Ángel Rodríguez Caballero v Fondo de Garantía Salarial (Fogasa) ECR [2002] I-11915, paras 30, 32.

${ }^{110}$ Lisbon Treaty (n 1) arts 2, 10, 18.

${ }^{111}$ Van Duyn (n 15) para 18; Krombach (n 16) para 22.

${ }^{112}$ Meidanis (n 50) 99.

${ }_{113}$ Mills (n 60) 216.

${ }^{114}$ Van Duyn (n 15) para 18; Krombach (n 16) para 23. 


\section{Differences between the usages of public policy in the two areas}

\subsection{Discriminatory nature}

Public policy is used to protect the values and principles of the domestic legal order in its use in both areas. There will thus sometimes be a certain bias against foreign goods, services, persons, capital or judgments. ${ }^{115}$ In Van Duyn, the CJEU allowed such a bias to take action. Practising the beliefs of the Church of Scientology was not forbidden for domestic nationals, but Mrs Van Duyn was still not granted leave to enter the United Kingdom due to her prospective employment by that institution. However, this part of the ruling was implicitly changed in Adoui and Cornuaille $v$ Belgium ${ }^{116}$ since it did not conform to the general prohibition of discrimination. ${ }^{117}$ In that case, Mrs Adoui and Mrs Cornuaille were to be expelled from Belgium since they worked in a bar 'which was suspect from the point of view of morals', 118 although that point of view of morals - prostitution - was not prohibited by Belgian legislation. The CJEU concluded that no public policy violation can be established if the activity in question is allowed for domestic nationals. ${ }^{119}$ In a fairly recent case, Josemans $v$ Maastricht, ${ }^{120}$ the Court came to a different conclusion, but tried to distinguish it from the Adoui and Cornuaille case. In Josemans, the issue was whether the municipality of Maastricht could forbid the consummation of marihuana for persons not residing in the Netherlands if the consummation is allowed for Netherlands' residents. The Court distinguished this case from the Adoui and Cornuaille case by observing that traffic in narcotics, except for medical uses and scientific research, is prohibited in all Member States, unlike prostitution. Having that in mind, Maastricht has the right to use the public policy exception to prohibit non-residents from entering well-known 'coffee shops' if their large influx actually disturbs public policy by increasing crime and illegal drugs sales. ${ }^{121}$ Without going into a detailed analysis of the reasonableness of this case, ${ }^{122}$ it can be concluded that in some instances the four freedoms public policy may be used as a device of discrimination.

\footnotetext{
115 Corthaut (n 2) 92 emphasises the existence of bias towards aliens.

116 Adui and Cornuaille (n 19).

117 Barnard (n 19) 482.

118 Adoui and Cornuaille (n 19) para 2.

119 ibid, para 7.

120 Josemans (n 85).

121 ibid, paras 79-84.

122 The case was criticised for the lack of legal reasoning and for the political motivation of the decision. See Marc A Jacobs, Precedents and Case-Based Reasoning in the European Court of Justice Unfinished Business (CUP 2014) 102.
} 
On the other side, it is hard to imagine that a Member State would refuse recognition of a judgment allowing something that exists and is allowed in that Member State. ${ }^{123}$ To give an example, if the State of recognition allows multiple damages, it cannot refuse a foreign judgment entailing the same level of damages. The public policy exception may be used only if recognition and enforcement 'would be at variance to an unacceptable degree with the legal order of the State in which enforcement is sought inasmuch as it infringes a fundamental principle'. ${ }^{124}$ This requirement is hard to reconcile with the scenario of non-recognition of the foreign judgment which entails something allowed in the Member State of recognition. ${ }^{125}$

To depict this difference, one could say that the uses of public policy in the two areas always work as a 'shield'126 of the domestic system, but the shield for the four freedoms may be a bit bigger and thus a bit more protective.

\subsection{Content of public policy - economic interest}

The CJEU has consistently held that economic interest cannot justify the restriction of the four freedoms. ${ }^{127}$ This is quite logical since the four freedoms are to be preserved and given priority due to their importance in an economic union such as the EU, so the protection of economic interest of one Member State towards the other should not be allowed. Otherwise, the creation of the internal market would be at stake since every country would be able to restrict the four freedoms by claiming economic disturbances that could arise from the free movement. ${ }^{128}$ The CJEU has recently decided that mere invocation of economic interests of a State may not constitute a public policy exception for the free move-

\footnotetext{
${ }^{123}$ None of the cases mentioned in the study on public policy by Hess and Pfeiffer (n 80) provides such a scenario.

${ }^{124}$ Krombach (n 16) para 37.

${ }^{125}$ Corthaut (n 2) 186-187.

126 Thomas Pfeiffer, 'Private International Law' in Wolfrum (ed), The Max Planck Encyclopedia of Public International Law (OUP 2011) para 21 as referred in Hess and Pfeiffer (n 80) 28. 127 Case 352/85 Bond van Adverteerders and others $v$ The Netherlands State [1988] ECR 02085, para 34; Case C-288/89 Stichting Collectieve Antennevoorziening Gouda and others $v$ Commissariaat voor de Media [1991] ECR I-04007, para 11; Case C-158/96 Raymond Kohll v Union des caisses de maladie [1998] ECR I-01931, para 41; Case C-385/99 VG Müller-Fauré v Onderlinge Waarborgmaatschappij OZ Zorgverzekeringen UA and EEM van Riet $v$ Onderlinge Waarborgmaatschappij ZAO Zorgverzekeringen [2003] ECR I-04509, para 72; Case C-137/04 Amy Rockler v Försäkringskassan [2006] ECR I-01441, para 24.

${ }^{128}$ The Member States have tried, for example, prescribing a mandatory employment form in domestic legislation to prevent foreign tourist and travel agencies from concluding a contract for the provision of services in order to secure industrial peace and avoid an impact on the economic sector of the State. Case C-398/95 Syndesmos ton en Elladi Touristikon kai Taxidiotikon Grafeion v Ypourgos Ergasias [1997] ECR I-03091.
} 
ment of judgments. ${ }^{129}$ However, having in mind that a party's interests are usually directly protected when the judgments public policy is invoked, there seems to be no reason why economic interest would not be allowed under that exception. It is plausible that the CJEU would allow the refusal of recognition and enforcement of a foreign judgment containing, for example, excessive damages or excessive lawyer's fees. In some Member States, similar situations already form a public policy violation and create a ground for the refusal of recognition and enforcement of foreign judgments under the Brussels I Regulation. Examples are France where an English judgment was refused since the uninsured employee had to pay around $85 \%$ of the damage whereas the employer was to bear only the rest, and Sweden where the recognition of a judgment was refused due to the level of damages awarded. ${ }^{130}$ It is true that the economic interest of a Member State is in question when talking about the four freedoms, whereas the fifth freedom concerns an individual's economic interest. Therefore, this difference in content mainly arises from the different manner of operation of the two public policy exceptions.

\subsection{Whose human rights are at stake?}

When it comes to human rights protection, there are some differences in the operation of the public policy restriction. The restriction of free movement of goods, services, persons or capital justified by the public policy of a Member State offers 'a protection for the sovereignty of the various Member States'. ${ }^{131}$ The four freedoms public policy juxtaposes the policy of a Member State to the individual interest of other Member States' nationals, goods, services and capital. The objects of protection are public/state interests that concern the whole society, as might be seen in the CJEU's case law related to that area in which the Member States mainly invoke provisions of public law that tend to protect the interests of all the citizens. ${ }^{132}$ It will rarely be seen that the four basic freedoms are restricted based on a threat to the human rights of only one individual, even if they form the fundamental principles of a legal order. On the other hand, when talking about public policy as a justification for the restriction of free movement of judgments, one can often pinpoint an individual whose rights are at stake, especially concerning human rights

\footnotetext{
${ }^{129}$ Case C-302/13 flyLAL-Lithuanian Airlines AS, in liquidation v Starptautiskā lidosta Rìga VAS and Air Baltic Corporation AS (Third Chamber, 23 October 2014).

${ }^{130}$ Hess and Pfeiffer (n 80) ch 3.2.2.

${ }^{131}$ Corthaut (n 2) 79.

${ }^{132}$ Examples are rules on the refusal of residence (Adoui and Cornuaille (n 19) or expulsion (Calfa (n 104)) regarding free movement of workers; rules on prior authorisation of capital investments regarding free movement of capital (Scientology International (n 94)), and rules on labelling with age classification (Case C-244/06 Dynamic Medien [2008] ECR I-505) regarding free movement of workers.
} 
related to procedural standards which are often invoked under the judgments public policy exception. ${ }^{133}$ It can thus be said that the judgments public policy actually has the strength to lift the protection of an individual's human rights to the public sphere. There must still be a belief that the right concerned is recognised by the State as essential.

The contrast is best seen in cases of violation of human rights, whereas the difference might diminish in other areas. In Krombach, an individual's right to a fair trial was violated which led to a refusal of recognition of the foreign judgment. In Omega, a British company's freedom of movement was restricted since their product, 'laserdrome', violated human dignity, a principle of the German constitutional order. It is to be noted that the dignity of all the members of German society, not a particular individual, was endangered. This difference is a product of the fact that recognition and enforcement of a judgment primarily concerns the parties to the judgment.

\section{Assessment of the comparison}

Restriction of the five basic freedoms encompassed in the notion of public policy is not easily determinable due to its variability in time and space which might lead to a lack of predictability and legal certainty in its operation. It can appear that public policy is the Procrustean bed, one notion to fit all intentions and applications. However, the truth is far from what it seems to be at first sight. The public policy exception is actually interpreted very strictly, which makes it operative in a very small number of cases. The CJEU's and national case law has shown that the public policy exception is reluctantly applied in both its areas of usage. ${ }^{134}$ In order to trigger the application of public policy, there must be a violation of a fundamental value, and this fundamentality must be scrutinised carefully. A good explanation of what may be considered to be public policy is that it 'refers to the minimal conditions that make possible the existence of the legal order and the State community to which it applies while they protect their integrity'. ${ }^{135}$ Therefore, the lack of predictability is diminished if one keeps in mind that the very base of a legal system must be endangered in order to invoke public policy.

It has been shown that the usages of the notion in the two areas elaborated in this paper are applied in a similar manner - their scope is interpreted restrictively, they concern a violation of a fundamental value/ interest/right and are both determined in a national context at the in-

\footnotetext{
${ }^{133}$ Hess and Pfeiffer (n 80) ch 3.2.2.

${ }^{134}$ See (n 92).

${ }^{135}$ Elena Rodriguez Pineau, 'European Union International Ordre Public' (1993-1994) 3 SYIL 43, 44.
} 
ternational level. The exact content of the notion is in both cases undeterminable in advance, precisely due to its variability. ${ }^{136}$ Some areas, like human rights, overlap and their violation may constitute a violation of public policy in both areas. Therefore, it is clear that the technique of application is similar, if not even identical.

However, the differences come into play when the addressees of human rights are considered. The judgments public policy will often protect the rights of the party subject to the judgment whose recognition and enforcement are being sought, whereas the four freedoms public policy protects society as a whole. Similarly, it is clear that the four freedoms public policy is never to be invoked to protect economic concerns, which is not true for the judgments public policy since it may protect the party's economic interest by protecting the State's public policy. Additionally, the four freedoms public policy might sometimes protect domestic nationals or residents and discriminate against foreign ones, which is unlikely for the judgments public policy.

This surely does not mean that there are several public policy concepts, only that the uses of the concept in various areas ask for different methods of operation. It is no exaggeration to say that each and every use $^{137}$ will demand strict interpretation and violation of a fundamental value and that there will most probably be some differences in the operation of the device and in its content.

\section{Conclusion}

The free movement of judgments is considered to be the fifth freedom which implies that it stands side by side the four basic freedoms. However, even this limited examination shows that no strict parallels should be drawn. EU law uses the same concept to justify the restriction of all five freedoms, but the concept of public policy does not operate identically in both cases. Only its international level is used, and in both areas the exception should operate similarly regarding its purely international and European level. The substantive and procedural dimensions show that specificities of the uses in the two areas ask for the more frequent occurrence of different dimensions. A restrictive interpretation is required regarding uses in both areas, and there should always be a violation of a fundamental value or principle that has to be determined according to each Member State's view. Although there are similarities in the application and determination of the 'two public policies', nuances between them mean that they merely overlap, but that they are never equal. Differences

\footnotetext{
136 ibid 50.

${ }^{137}$ Another use may be found in, for example, the Succession Regulation (n 30), Rome I Regulation (n 31), Rome II Regulation (n 32), Rome III Regulation (n 33).
} 
exist regarding the protection of economic interest, the discriminatory nature of the four freedoms public policy and the protection of the fundamental rights of the addressees. Still, there is just one concept of public policy in the EU, or, better to say, each Member State has its own and only one public policy. The fact that it operates differently in different areas does not make it split into or create two separate notions. The core of public policy is always the same - protecting all or certain citizens' interests and rights. 
